\title{
COVID-19 and State Failure: A Double Whammy for Trade Unions and Labour Rights
}

\author{
K. R. Shyam Sundar ${ }^{1}$
}

Published online: 14 September 2020

(c) Indian Society of Labour Economics 2020

\section{Labour Market and Industrial Relations System-Pre-COVID-19}

The Constitution of India, the International Labour Standards (ILS) framework of the ILO (comprising Conventions and Recommendations) and its pradigms like the Decent Work, Judge-made law (i.e. judgments delivered primarily by the Supreme Court) and social dialogue (both tripartite and bipartite) together determine the labour laws and rule-making processes in the Industrial Relations System (IRS) in India. This has been the classic framework that was followed largely during the command economy period in India, i.e. 1947-1991. With economic liberalisation, employers demand labour law governance (inspection) and reforms to afford labour flexibility to them (shortly, Labour Market Flexibility, LMF).

Notwithstanding protests by trade unions, several state governments have introduced at various times, reforms to afford LMF to employers. According to the Periodic Labour Force Survey (PLFS) 2017-2018, 83.5\% of the 260 million workers in the non-agricultural workers work in the informal economy. Around $70 \%$ did not have a written employment contract; around half of them did not have access to any form of social security and paid leave.

Thus, informality and weak labour rights characterised the labour market and the IRS during the COVID-19 period. COVID-19 has greatly shaken up the labour market, and this period has witnessed ineffable sufferings and woes of workers.

\section{COVID-19, the State and Employers}

The sudden national lockdown introduced on March 25 initially for 21 days was extended with varying relaxations till May 31. Later even as un-locking took place, local lockdowns have continued. Lockdowns meant near-total stoppage of economic activity (not covered by labour laws). Trade unions argue that during the lockdown

K. R. Shyam Sundar

krshyams@xlri.ac.in

1 XLRI, Xavier School of Management, Jamshedpur, India 
period, the state should assume full control and even responsibility of the economy and welfare of the workers. As the economy gradually even fitfully unlocked, employers came into the picture. So, trade unions have engaged mostly with the state (including the judiciary) and to some extent with employers.

The Labour Ministry merely issued advisories to employers not to retrench workers and pay wages to workers during the lockdown and conspicuous by its absence. The Ministry of Home Affairs (MHA) issued a directive (on March 29) to employers of factories and shops and establishments to pay full wages to employees during the lockdown period, March 29 to May 17 which as we note below was ineffective. Critics have argued that the relief measures announced by the central government are parsimonious and even ill-directed (Ghosh 2020). Along with the relief measures for COVID-affected firms and workers, the Central government also introduced structural reforms in eight sectors like coal, defence, etc. like introduction of commercial coal mining, increase in FDI in defence manufacturing from $49 \%$ to $74 \%$, rationalisation of total operating companies to four in strategic sectors (i.e. creating oligopolies in them), and enabling greater role for the private sector in the economy. It must be noted that the structural reforms are not aimed at providing 'direct or indirect relief' to firms or workers but constitute neoliberal reform measures to restructure the product market.

Several state governments amended the Factories Act to extend maximum work hours from 8 to 10-12 with differential overtime pay. Madhya Pradesh and Uttar Pradesh have issued ordinances diluting or suspending important labour laws. Several states have increased the thresholds of critical labour laws like Chapter V-B of Industrial Disputes Act, 1948 (IDA), Factories Act, 1948, the Contract Labour (Regulation and Abolition) Act, 1970, and introduced fixed-term employment. Put simply, these are substantial reforms hurting a wide range of labour rights (Shyam Sundar and Sapkal 2020; Shyam Sundar 2020a, b).

Employees were partially or fully paid and often not paid their wages during the lockdown period (D’Souza 2020; Economic Times 2020). During the post-lockdown period, a small proportion of workers were re-employed and often at reduced wages and they were refused wages for the lockdown period. Employers have sought resignations from workers with benefits or threaten them with retrenchment or as in the case of Air India, employer asked the staff to go on extended leave without pay. In many cases (e.g. Bajaj Auto, Air India, health and care sectors), employees have contracted COVID-19 virus and few succumbed to death (Indian Express 2020; ToI 2020). Frontline workers especially the vulnerable government-scheme-based employees like Anganwadi and ASHA suffered much.

\section{Trade Unions' Role during COVID-19}

The adverse legal and labour market conditions have pushed trade unions to adopt several strategies to combat them and protect labour rights. Trade unions' strategies comprise the following, viz. write memorandums of appeal and protests to the governments (central and state), demand dialogue with government, engage in negotiations with employers, struggles, and seeking the intervention of ILO and a 
global union, International Trade Union Confederation (ITUC)]. Given the sensitive COVID-19 context, trade unions needed to adopt softer and distant methods to influence public policy and extend welfare measures to their constituents. Organisationally, both at national and state levels, like-minded Central Trade Unions (CTUs) have formed coordination fronts (CTUs). At the national level, there is a rift between Bharatiya Mazdoor Sangh (BMS) and the ten trade unions (INTUC, AITUC, HMS, CITU, AITUC, AIUTUC, TUCC, SEWA, AICCTU, LPF, UTUC) who have formed the National Platform of Central Unions (NPCU). However, their agenda, thanks to neo-liberal regulatory regime, remains the same despite their differences.

\section{Memorandum of Appeal and Protests}

The CTUs have used the memorandum method quite extensively given the pandemic-imposed constraints. They have appealed to the President, the Prime Minister, and the Union Labour Minister. The CTUs and their allies have among other things(a) demanded multiple welfare measures including direct benefit transfer to non-taxpaying workers, enhanced pension, payment of cash and other forms of assistance to workers from their welfare boards, wide-covering fiscal reliefs, food security (including universal PDS), and protective health gear to and safety for the frontline workers, (b) protested against the labour market incidents noted above and provided concrete instances to support their claims, (c) expressed concern at the high and rising unemployment, (d) supported the "industry" their demands for subsidies, and (e) asked for dialogue with them. Their demands and concerns covered all kinds of workers including scheme-based employees (MGNREGA, Anganwadi, ASHA Mid-day meals, etc.) and contract, casual and migrant workers in their petitions. Their major demands are: reliefs to surviving migrant workers and compensation to their families, free ration, Direct Benefit Transfer (DBT) of 7500, enhanced pension of 3000 to all non-income tax paying workers for six months, Aadhar-linked smart cards to all workers, withdraw the proposed privatisation measures and labour law changes, rise in MGNREGA wage to ₹500 per day, recovery of loans from wilful defaulters, increased budgetary allocation to the health, education, care and agriculture sectors, a fund for social security for unorganised workers, urban employment assurance scheme, protection for frontline workers, etc. The inclusivity and the width of their protest agenda and of employees are significant.

\section{Social Dialogue Deficits}

Trade unions have appealed to the central government to hold dialogue with them and criticised it for holding "web-based consultations". In fact, having ratified the ILO Convention, Tripartite Consultation (International Labour Standards) Convention, 1976 (C144), India must hold social dialogue to frame the economic and social policies and laws. It is reported that the Labour Minister twice met CTUs during May 2020 and they were ineffective (Nath 2020). Trade unions including BMS complained of the absence of social dialogue at both national and state levels. The 
governments introduced policies and changes in laws unilaterally (Shyam Sundar $2020 \mathrm{a}, \mathrm{b})$. The aggressive reforms and inadequacies in announcement and execution of relief measures have rather forced the CTUs to go for direct action.

\section{Protests and Struggles}

Trade unions' protests have taken several forms such as petitions, protest letters, "demands day", posts on social media and WhatsApp, black badges, lunch meetings, and raising concerns due to the COVID-19 exigencies. During the partial unlock times, they have conducted open collective protests though often constrained by COVID-19 regulations, viz. demonstrations (at street corners, in front of their houses and government offices), letters to district authorities, hunger strike, processions, courting arrests, and strikes, etc. The protests during the lockdown period shifted from the streets to the social media, processes and mobilisation.

Owing to rifts in the trade union movement, BMS conducted its country-wide protests on May 20 and on May 22 and July 3 the NPCU did ${ }^{1}$.

There were strikes at the factory and industry levels also. For example, workers at Euro Clothing Company factory (owned by Gokaldas Exports) struck work protesting the closure of it and retrenchment of more than 1000 workers due to cancellation of orders by global brand H\&M and took the battle to the social media which made H\&M hold dialogue with the trade union at the plant (Crumps 2020). On June 10-11, 2020, the coal workers' unions including BMS protested the central government's reforms such as commercial mining, privatisation of Coal India. They followed it up with strike during July 2-4 as negotiations with the government failed as the latter stuck to its policies ${ }^{2}$. The NPCU successfully organised an all-India strike of scheme-based employees on August 7-8 and Save India Day on August 9, 2020.

\section{Global Action}

Since the government was not responding to their agitations and representations, the NPCU made a detailed representation of aforementioned state policies and laws to the Director General (DG) of ILO and the International Trade Union Council (ITUC) to seek intervention. Both expressed serious concern at the reported developments, appealed to the Prime Minister to uphold the international commitments made by India and encouraged social dialogue. The personal intervention by the DG of ILO is an exceptional event (Joseph 2020), and it reflects the seriousness of adversities faced by workers in India. In fact, the central government responded to these pressures positively. It affirmed that complete suspension of labour laws and

\footnotetext{
1 (see https://www.deccanherald.com/national/bms-protests-against-dilution-of-labour-laws-demandspayment-of-wages-for-lockdown-period-840047.html; http://citucentre.org/659-22nd-may-nationwide -protest-day-observed-by-trade-unions)

2 (see for details, https://www.ituc-csi.org/IMG/pdf/2020_july_strike_press_release.pdf)
} 
those reforms such as the extension of work hours contrary to ILO standards would not be permitted (Arnimesh 2020; Financial Express 2020).

\section{Legal Action}

Trade unions in India generally shy away from litigation for two reasons. First, the Supreme Court (SC) has delivered adverse judgments during the post-reform period which weakened or diluted labour rights (e.g. judgments relating to contract and casual employees) period. Second, the judge-made laws cannot be reversed. The SC's handling of migrant workers' issues during COVID-19 has been severely criticised even by an ex-SC Justice (Lokur 2020). Adjudicating on the clutch of petitions placed by employers on MHA's March 29 Directive (noted above), the SC firstly ordered no coercive action on wage-defaulting employers (June 4 order) and later left the wage payment issues to direct negotiations between employers and employees (Live Law 2020). These decisions by the SC do not inspire confidence in trade unions.

\section{Conclusions}

A pandemic of this magnitude should ideally create cooperation between the state and trade unions to deal with issues relating to IRS. However, COVID-19 has witnessed the continuation of neo-liberal state policies followed during the pre-COVID-19 period such as aggressive labour law and governance reforms and social dialogue deficits. These measures, combined with the pandemic-induced effects, have intensified informality and precarity in the labour market. State unilateralism and aggressive reforms have forced trade unions on the conflict path. Trade unions have had to deal with numerous adversities and multiple issues during COVID-19 period. They have resorted to multiple strategies to protect and secure labour and even people's rights to livelihood.

On the other hand, even as trade unions defend numerous rights, their voices are far more vocal on the conventional issues like privatisation, FDI, etc., rather than issues like occupational safety and health. For example, during May-June 2020, India witnessed 30 industrial accidents, killing 75 and injuring more than 100 (Industriall 2020). Occupational Safety and Health (OSH) issues have not received the attention they deserve from trade unions. The CTUs are losing the plot by their excessive focus on issues at the national level since labour law reforms are taking place at the regional level. Trade unions must share the responsibility for non-implementation of all laws concerning the unorganised workers which worsened the plight of these workers during COVID-19 period. Even now trade unions are not focussing adequately on these critical issues. Trade unions need to do a lot of work to stay relevant even as they challenged more stridently by neo-liberal politics. 


\section{Important Correspondences from Trade Unions}

1. Memorandum submitted through District Administration, BMS, to the President of India, May 28.

2. Request for Coverage in Media, May 11, 2020, NPCU

3. Joint Circular from CTUs, dated July 22, 2020

4. Letter to the President of India, July 24, 2020

5. Urgent Issues of Scheme Workers in the Context of COVID-19 Pandemic, July 1,2020

6. Strike Notice by NPCU to the Secretary, Departments of Labour/Women and Children Development/Health/Education

7. Press Statement by BMS announcing Nationwide Agitation in Solidarity with the Fight Against the Anti-Worker Ordinances of UP, MP, Gujarat, and also other Labour Issues, July 14, 2020

8. Sacrificing Workers on Altar of “development", Working People's Charter, May 2020 (undated)

9. Letter to the Prime Minister from ITUC, May 13, 2020

10. Letter to Prime Minister: Not to Repeal Inter-State Migrant Workmen Act, 1979, May 10, 2020, by MPCU

11. Secretary, Ministry of Labour and Employment, Termination and wage cut (11th Letter) by CITU, April 17, 2020

12. Memorandum, Legislation of Labour Codes by Stealth, April 13, 2020, by MPCU

13. Joint Opposition to any move to amend Factories Act, 1948, April 13, 2020

14. Letter to Labour Minister, April 1, 2020 by MPCU

15. Letter to Prime Minister, March 26, 2020

\section{References}

Arnimesh, Shanker 2020. Modi govt says suspension of labour laws not reform, raises concern over states changing laws, The Print, May 27, https://theprint.in/india/modi-govt-says-suspension-oflabour-laws-not-reform-raises-concern-over-states-changing-laws/429644/.

Crumps, James 2020. Indian factory workers protest after 'H\&M cancels orders' leaving 1,000 jobless, Independent, June 24, https://www.independent.co.uk/news/world/asia/hm-garment-worke rs-factory-india-jobs-a9579856.html.

D'Souza, Ornella 2020. Layoffs, salary cuts become new COVID-19 norms, The New Indian Express, May 26.

Economic Times 2020. Post COVID Lockdown: Workers may face pay cuts, disciplinary action on failure to rejoin companies, Economic Times, May 11.

Financial Express 2020. State govts cannot increase working hours beyond eight, Centre tells parliamentary panel, Financial Express, July 20.

Ghosh, Jayati 2020. A critique of the Indian government's response to the COVID-19 pandemic, Journal of Industrial and Business Economics, July,.

Indian Express 2020. Bajaj Auto unions demand factory halt after 250 workers test positive for COVID, Indian Express, July 6. 
Industriall 2020. India's safety crisis: industrial accidents during COVID-19 kill at least 75, http:// www.industriall-union.org/indias-safety-crisis-industrial-accidents-during-covid-19-kill-at-least -75 .

Joseph, M.P. 2020. The Centre asks for and gets 'one tight slap' from ILO, The Week, May 30, https:// www.theweek.in/news/biz-tech/2020/05/30/opinion-the-govt-asks-for-and-gets-one-tight-slap-fromilo.html.

Live Law 2020. SC Gives Option To Establishments And Workers To Negotiate On Full Payment Of Wages, Regardless Of MHA Order, Live Law, June 12, https://www.livelaw.in/top-stories/sc-gives -option-to-establishments-and-workers-to-negotiate-on-full-payment-of-wages-regardless-of-mhaorder-158207.

Lokur, Madan B 2020. Justice Madan Lokur: Supreme Court Deserves an 'F' Grade For Its Handling of Migrants, The Wire, May 28, https://thewire.in/law/after-humanitarian-law-died-a-million-death s-the-supreme-court-has-finally-stirred-itself.

Nath, Damini 2020. Coronavirus lockdown I Centre urges unions to convince labour to stay, return to work, The Hindu, May 7.

Shyam Sundar, K.R. and Rahul Sapkal 2020. Changes to Labour Laws by State Governments Will Lead to Anarchy in the Labour Market, EPW Engage, June 5, 2020.

Shyam Sundar, K.R. 2020a. No Dialogue with Trade Unions, India's Labour Laws Are Now a Product of Unilateralism, The Wire, July 7, 2020.

Shyam Sundar, K.R. 2020b. Who needs national codes and laws? The Hindu Business Line (Web Edition), July 22, 2020.

Times of India (ToI) 2020. Air India says some employees died of COVID-19..., Times of India, July 21.

Publisher's Note Springer Nature remains neutral with regard to jurisdictional claims in published maps and institutional affiliations. 